\title{
PENGEMBANGAN KELOMPOK USAHA MANDIRI MASYARAKAT (KUMM) MENUJU KOPERASI SYARIAH
}

\author{
Nurul Huda dan Nazwirman \\ Program Magister Manajemen, Universitas YARSI, Jakarta \\ Email: nurul.huda@yarsi.ac.id
}

\begin{abstract}
Community Service that will be done is part of Tridharma Higher Education activities as well as efforts to contribute to develop micro business. The Object of Community Service is some Majelis Taklim Independent Community Business Group (KUMM) is located in the district of Tanjung Priok.

Implementation of the activities of the participants assessed the level of satisfaction both from the dimensions of the speaker, training materials, atmosphere, and means. Knowledge skills from before the activities are carried out as evidenced by the pre and post test. The objective is to establish Sharia Cooperative as an instrument of business development of KUMM by using training and mentoring approach.
\end{abstract}

Keywords: Micro Business, KUMM, Sharia Cooperative, Trainer, Assistance

\section{PENDAHULUAN}

Koperasi syariah merupakan lembaga keuangan mikro syariah dengan sasaran pada ekonomi rakyat yang berupaya mengembangkan usahausaha produktif dan investasi dengan sistem bagi hasil. Tujuan utamanya meningkatkan kualitas ekonomi pengusaha mikro dan kecil, sebagai bagian dari upaya mengentaskan kemiskinan.

Koperasi syariah atau BMT memiliki dua fungsi yaitu : Pertama, Baitul Maal menjalankan fungsi untuk memberi santunan kepada kaum miskin dengan menyalurkan dana ZIS (Zakat, Infaq, Shodaqoh) kepada yang berhak;
Kedua, Baitul Taamwil menjalankan fungsi menghimpun simpanan dan membiayai kegiatan ekonomi rakyat dengan menggunakan Sistem Syariah.

Sebelum era 1990-an BMT/Koperasi Syariah banyak digerakkan oleh tokoh-tokoh masyarakat, aktifis-aktifis masjid karena memang BMT/Koperasi Syariah tumbuh dari sana. Mulai 1993, lembaga nirlaba seperti Dompet Dhuafa (DD) mulai mengembangkan BMT/Koperasi Syariah. Menurut data dari Pusat Inkubasi Bisnis Usaha Kecil (Pinbuk), dalam beberapa tahun terakhir BMT/Koperasi Syariah selalu mengalami pertumbuhan sedikitnya 
20\%. Meski demikian, harus diakui bahwa realitas dinamika BMT/Koperasi Syariah di lapangan tidak selalu bagus, bahkan ada BMT/Koperasi Syariah yang kemudian tumbang, gagal, rugi dan kemudian mati, tidak berjalan lagi. Di antara yang menyebabkan gagalnya pengelolaan BMT/Koperasi Syariah tersebut menurut Aziz (2008), pertama adalah kurangnya persiapan sumber daya manusia (SDM) pengelola, baik dari sisi pengetahuan atau ketrampilan dalam mengelola BMT/Koperasi Syariah, terutama masalah pengguliran pembiayaan. Kasus riil adalah banyaknya pembiayaan yang tidak tertagih alias macet. Kedua, lemahnya pengawasan pada pengelolaan, terutama manajemen dana dan kurangnya rasa memiliki pengelola BMT/Koperasi Syariah.

Kelompok Usaha Mikro Mandiri (KUMM) ini berada di wilayah kecamatan Tanjung Priok di beberapa kelurahan yaitu: KUMM Al-KautsarSungai Bambu, KUMM An NajmuPapanggo, KUMM KhoirussalamTanjung Priok dan KUMM Khairunnisa dan KUMM As Sakinah-Kebon Bawang di bawah pembinaan Yayasan Oase Anak Bangsa. Berdasarkan hasil survey awal yang dilakukan dapat diketahui bahwa KUMM ini adalah program Pemberdayaan Ekonomi dari Majelis Ta'lim. Jumlah pengurus sebanyak 3-5 orang dengan beranggotakan sebanyak 20 - 35 orang. .

\section{Perumusan Masalah}

Minat yang tinggi Kelompok Usaha Mikro Mandiri (KUMM) ini berada di wilayah kecamatan Tanjung Priok untuk mengembangkan usaha anggota terhambat pada kendala teknis seperti pengelolaan dana usaha masih individu, tentu hal ini harus diperbaiki. Hal ini menjadi tantangan sendiri untuk membantu pengelolaan usaha yang dilakukan tersebut dengan pendekatan Islami. Pendekatan Islami digunakan karena anggota KUMM sekaligus anggota Majlis Tak'lim. Selain itu persoalan untuk menambah dana usaha juga menjadi persoalan tersendiri. Pengabdian Kepada Masyarakat yang dilakukan yaitu menjelaskan dan melatih tetang koperasi syariah dan bagaimana mendirikan organisasi sebagai sarana untuk meningkatkan modal usaha anggota KUMM.

\section{Tujuan Kegiatan}

Berdasarkan uraian dalam permasalahan maka tujuan dari kegiatan 
pengabdian kepada masyarakat ini yaitu

1. Memberikan pemahaman bagi Seluruh pengurus dan Anggota KUMM Koperasi Syariah/BMT

2. Memberikan ilustrasi mekanisme membentuk KUMM Koperasi Syariah/BMT

3. Mendampingi proses pembentukan Koperasi Syariah/BMT

\section{KAJIAN TEORI}

Koperasi Syariah/ Baitul Maal Wa Tamwil

Secara bahasa Baitul-Mâl dibentuk dengan meng-idhâfah-kan kata Bait artinya rumah, kepada al-Mâl artinya harta. Kata al-mâl ini mencakup semua jenis harta. Menurut jamaah, almâl adalah benda berharga seperti emas dan perak. Lalu digunakan untuk menyebut segala yang dimiliki. Yang sudah diketahui menurut perkataan orang arab, setiap apa saja yang dikumpulkan dan dimiliki adalah mâl (harta). Menurut Ibn al-Atsir, mâl asalnya adalah emas dan perak yang dimiliki, lalu dimutlakkan untuk menyebut semua benda berharga yang dikumpulkan dan dimiliki. Dengan demikian, secara harfiah Baital-mâl artinya rumah harta, yaitu rumah tempat untuk menyimpan harta berupa semua jenis benda berharga yang dikumpulkan dan dimiliki.

Adapun secara terminologis (ma'na ishtilahi), sebagaimana uraian Abdul Qadim Zallum1, Baitul Maal adalah suatu lembaga atau pihak (Arab: al jihat) yang mempunyai tugas khusus menangani segala harta umat, baik berupa pendapatan maupun pengeluaran negara. Jadi setiap harta baik berupa tanah, bangunan, barang tambang, uang, komoditas perdagangan, maupun harta benda lainnya di mana kaum muslimin berhak memilikinya sesuai hukum syara' dan tidak ditentukan individu pemiliknya, walaupun telah tertentu pihak yang berhak menerimanya, maka harta tersebut menjadi hak Baitul Maal, yakni sudah dianggap sebagai pemasukan bagi Baitul Maal. Secara hukum, harta-harta itu adalah hak Baitul Maal, baik yang sudah benar-benar masuk ke dalam tempat penyimpanan Baitul Maal maupun yang belum.

Secara konseptual, BMT memiliki dua fungsi (Huda, Putra, Novarini, Mardoni, 2016) :

1. Baitul Maal $($ Bait = Rumah, Maal = Harta) menerima titipan dana ZIS 
(Zakat, Infaq dan Shadaqah) serta mengoptimaalkan distribusinya dengan memberikan santunan kepada yang berhak (para ashnaf) sesuai dengan peraturan dan amanah yang diterima.

2. Baitut Tamwil (Bait = Rumah, atTamwil = Pengembangan Harta) melakukan kegiatan pengembangan usaha-usaha produktif dan investasi dalam meningkatkan kualitas ekonomi pengusaha mikro dan kecil terutama dengan mendorong kegiatan menabung dan menunjang pembiayaan kegiatan ekonominya.

Sebagai lembaga usaha yang mandiri, BMT memiliki ciri-ciri sebagai berikut (Aziz, Hatta, 2006 ; Huda, Putra, Novarini, Mardoni, 2016) :

1. Berorientasi bisnis, yakni memiliki tujuan mencari laba bersama dan meningkatkan pemanfaatan segala potensi ekonomi yang sebanyakbanyaknya bagi para anggota dan lingkungannya.

2. Bukan merupakan lembaga sosial, tetapi dapat dimanfaatkan untuk mengelola dana sosial umat seperti zakat, infak, shadaqah, hibah dan wakaf.

3. Lembaga ekonomi umat yang dibangun dari bawah secara swadaya yang melibatkan peran serta masyarakat di sekitarnya.

4. Lembaga ekonomi milik bersama antara kalangan masyarakat bawah dan kecil serta bukan milik perorangan atau kelompok tertentu di luar masyarakat sekitar BMT. Dukungan masyarakat terhadap optimaalisasi peran BMT sangat penting, sebab lembaga BMT didirikan dari, oleh dan untuk masyarakat. Segala ide dasar dan tujuan dari didirikannya BMT antara lain adalah untuk kepentingan masyarakat itu sendiri dan dilakukan secara swadaya dan berkesinambungan

\section{Usaha Mikro}

Sasaran Strategis Kementerian Koperasi dan UKM untuk tahun 20152019 disusun berdasarkan dengan Tujuan yang akan diwujudkan Kementerian Koperasi dan UKM dalam lima tahun mendatang, serta dengan berpedoman pada sasaran nasional di bidang Koperasi dan UMKM yang dituangkan di dalam RPJMN 201520192, yaitu:

1) Meningkatnya kontribusi KUMKM dalam perekonomian melalui 
pengembangan komoditas berbasis koperasi/sentra di sektor-sektor unggulan;

2) Meningkatnya daya saing koperasi dan UMKM;

3) Meningkatnya wirausaha baru dengan usaha yang layak dan berkelanjutan;

4) Meningkatnya kualitas kelembagaan dan usaha koperasi, serta penerapan praktek berkoperasi dan yang baik oleh masyarakat.

Karakteristik utama UMKM adalah kemampuannya mengembangkan proses bisnis yang fleksibel dengan menanggung biaya yang relatif rendah (Warsono et al., 2010). Namun, salah satu tantangan utama yang dihadapi UMKM adalah terkait dengan pengelolaan dana. Ketidakberesan pengelolaan dana seringkali menjadi pemicu terjadinya kegagalan UMKM. Para pelaku UMKM memang perlu mendapatkan sosialisasi dan pembinaan baik secara finansial dan non finansial (Irawan, 2013). Inisiatif utama dalam pengelolaan dana adalah dengan mempraktikkan akuntansi dengan baik.

Pelaksanaan pembukuan akuntansi untuk menghasilkan laporan keuangan merupakan hal yang masih sulit bagi UMKM. Keterbatasan pengetahuan pembukuan akuntansi, rumitnya proses akuntansi, dan anggapan bahwa laporan keuangan bukanlah hal yang penting bagi UMKM menjadi alasan bagi UMKM untuk tidak melakukan pembukuan secara akuntansi. Banyak kasus-kasus para UMKM yang tidak melakukan pembukuan dengan benar atau bahkan tidak sama sekali, mengakibatkan mereka juga tidak mengetahui perkembangan usahanya (Murtiningtyas, 2013). Bahkan terkadang pencatatan yang dilakukan oleh UMKM hanya sebatas jumlah pembelian dan penjualan yang terjadi dalam kegiatan operasionalnya (Mutiah, Harwida dan Kurniawan, 2011). Terlebih lagi bentuk UMKM yang lebih didominasi perusahaan perseorangan mengakibatkan kurangnya kebutuhan untuk membuat laporan keuangan yang sesuai standar akuntansi. Bentuk perusahaan perseorangan juga menyebabkan pemisahan keuangan bagi diri pribadi pemilik usaha dengan kegiatan usahanya seringkali juga tidak dilakukan. 


\section{PELAKSANAAN KEGIATAN}

\section{Waktu Kegiatan}

Pelaksanaan Pengabdian kepada Masyarakat sudah dilaksanakan pada hari Rabu tanggal 22 November 2017. Melibatkan tiga pihak utama, yaitu:

1) Program Magister Manajemen Sekolah Pascasarjana Universitas YARSI Univesitas Yarsi selaku pihak yang akan menjalankan peran memberikan pemahaman terkait terbentuknya koperasi syariah/BMT dan pendampingan

2) Yayasan OASE Anak Bangsa selaku Yayasan yang menaungi Seluruh KUMM
3) KUMM Al-Kautsar-Sungai Bambu,

KUMM An Najmu-Papanggo,

KUMM Khoirussalam-Tanjung

Priok dan KUMM Khairunnisa dan KUMM As Sakinah-Kebon Bawang Kemudian mempersiapkan Standing Banner, Kuesioner, Akomodasi, dokumentasi dan Konsumsi

\section{Metode Kegiatan}

Metode pelaksanaan yang digunakan oleh tim pengabdian masyarakat adalah metode pelatihan dan pendampingan. Gambaran metode pendampingan yang dilakukan (Gambar1):

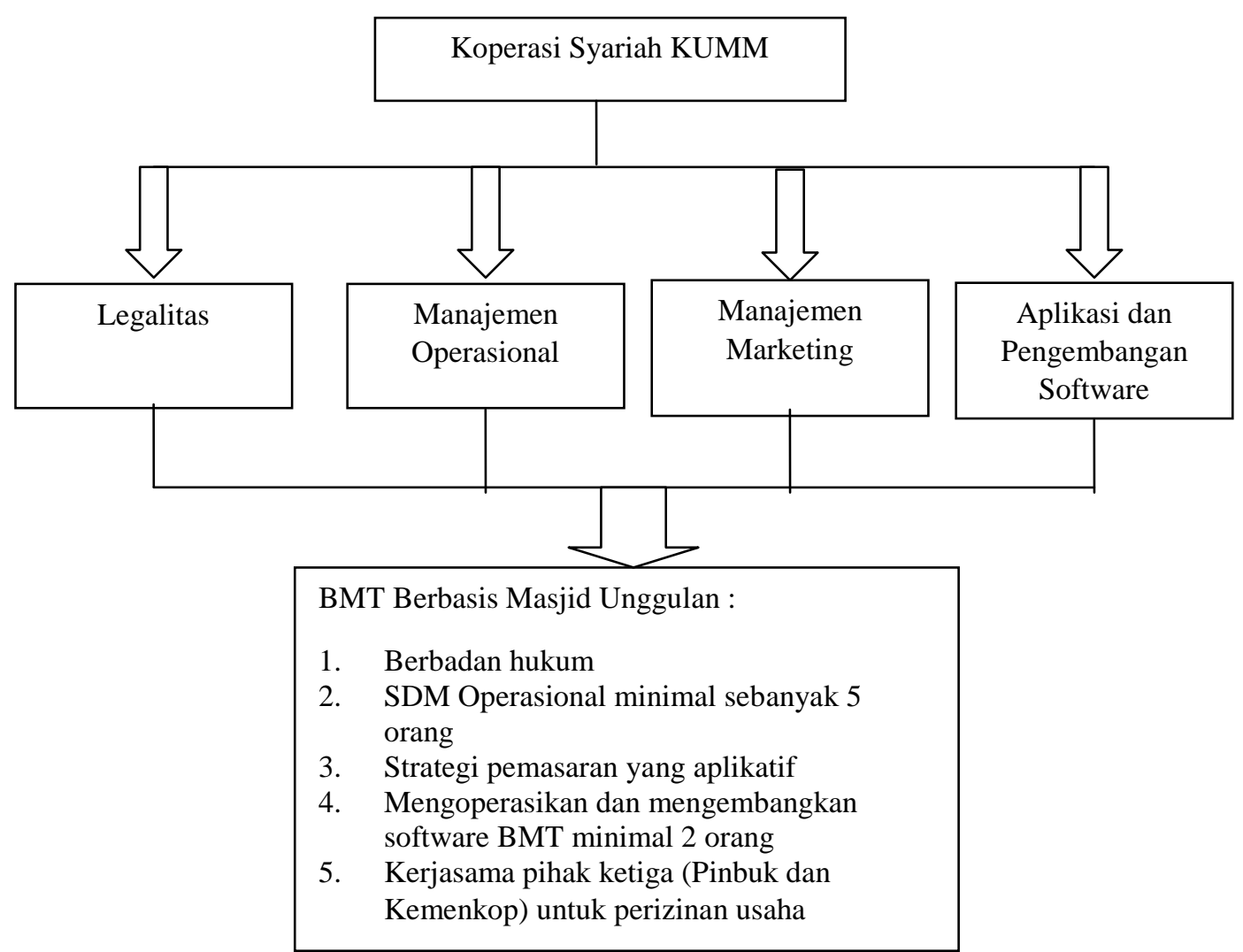




\section{Gambar 1. Metode Pendampingan Program Pengabdian Masyarakat}

Kegiatan ini melibatkan Tiga pihak utama, yaitu:

1) Program Magister Manajemen Sekolah Pascasarjana Universitas YARSI Univesitas Yarsi selaku pihak yang akan menjalankan peran memberikan pemahaman terkait koperasi syariah bagi KUMM dan Program pendampingan

2) Yayasan OASE Anak Bangsa selaku Yayasan yang menaungi Seluruh KUMM

3) KUMM Al-Kautsar-Sungai Bambu, KUMM An NajmuPapanggo, KUMM Khoirussalam-Tanjung Priok dan KUMM Khairunnisa dan KUMM As Sakinah-Kebon Bawang

\section{Evaluasi}

Dilakukan evaluasi yaitu tahap pertama Evaluasi yang dilakukan yaitu melihat dampak sharing terhadap pengetahuan Seluruh pengurus dan Anggota KUMM tentang dasar pengelolaan suatu usaha sebelum dan sesudah sharing (pre test dan post test), tentang konsep Islam dalam mengelola usaha dan akuntabilitas usaha sebelum dan sesudah pelatihan dari sisi Kognitif, Afektif dan Psikomotorik melalui uji beda score. Tahap kedua evaluasi kemajuan rencana proses pendirian Koperasi Syariah bagi KUMM..

Metode pengambilan sampel adalah dengan menggunakan metode purposive sampling dari populasi lima majelis taklim yang tergabung oleh Yayasan Oase Anak Bangsa Cabang Sungai Bambu Tanjung Priok. Sampel diambil seluruh Jemaah majelis taklim yang hadir pada saat sosialisai, dan sebagian pelaku usaha KUMM.

\section{HASIL DAN PEMBAHASAN}

\section{Hasil Deskriptif Peserta}

Hasil pelaksanaan kegiatan Pengabdian Kepada Masyarakat pada Oase Anak Bangsa di Tg. Priok menghasilkan. 
Tabel 1. Demografi Peserta

\begin{tabular}{cllcc}
\hline No & Karekteristik & \multicolumn{1}{c}{ Keterangan } & Jumlah & Persentase \\
\hline 1 & Jenis Kelamin & Laki-laki & 0 & 0 \\
& & Perempuan & 35 & 100 \\
2 & Usia & 17 sd 25 Tahun & 0 & 0 \\
& & 26 sd 39 Tahun & 12 & 54 \\
& & 40 sd 55 Tahun & 19 & 34 \\
3 & \multirow{3}{*}{ Pendidikan } & Lebih 55 Tahun & 4 & 12 \\
& & SD & 3 & 9 \\
& & SMP & 13 & 37 \\
& & SMU & 14 & 40 \\
& & Akademi & 5 & 14 \\
\multirow{4}{*}{4} & \multirow{4}{*}{ Pekerjaan } & Sarjana & 0 & 0 \\
& & Pascasarjana & 0 & 0 \\
& & Ibu Rumah Tangga & 22 & 63 \\
& & Wiraswasta & 12 & 34 \\
& & Karyawan Swasta & 0 & 0 \\
& & Pegawai Negeri/TNI/Polri & 1 & 3 \\
& & Pensiunan & 0 & 0 \\
\hline
\end{tabular}

Sumber: Hasil Olahan (2017)

Dari Tabel tampak bahwa jumlah peserta kegiatan sebanyak 35 orang dan seluruhnya (100 persen) peserta adalah berjenis kelamin perempuan. Hal ini karena peserta seluruhnya ibu-ibu majelis taklim yang juga terlibat dalam kegiatan Kelompok Usaha Mandiri Masyarakat.

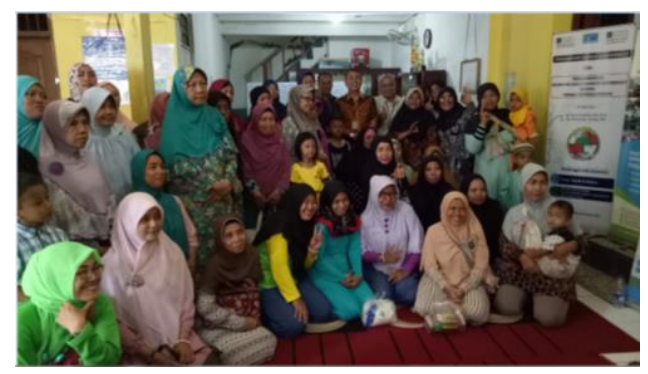

Gambar 2. Peserta Pelatihan

\section{Koperasi Syariah}

Usia peserta terdiri dari 54 persen atau 19 orang peserta berusia antara $40 \mathrm{~s} / \mathrm{d} 55$ tahun. 34 persen atau 12 orang peserta berusia antara $26 \mathrm{~s} / \mathrm{d}$
39 tahun, dan 12 persen atau 5 orang berusia lebih dari 55 tahun. Ini menunjukan bahwa peserta sebagain besar masih berusia produktif.

Pendidikan peserta terdiri dari 40 persen atau 14 orang peserta berpendidikan SMU. 37 persen atau 13 orang peserta berpendidikan SMP. 14 persen atau 5 orang peserta berpendidikan Akademi, dan 9 persen atau 3 orang peserta berpendidikan SD. Ini berarti pendidikan peserta lebih cenderung samapai sekolah menengah.

Pekerjaan peserta terdiri dari 63 persen atau 22 orang peserta sebagai ibu rumah tangga. 34 persen atau 12 orang peserta berwirausaha. 3 persen atau 1 orang sebagai Pegawai Negeri. Ini menunjukan bahwa beserta sebagian besar ibu rumah tangga dimana sangat 
mungkin dapat memanfaatkan waktu luangnya untuk usaha.

\section{Tingkat Kepuasan Peserta}

Mengetahui tingkat kepuasan peserta dalam pelaksanaan pengabdian kepada masyarakat memberikan sebanyak 19 (sembilan belas) indikator pertanyaan yang terdiri dari 4 (empat dimensi) yaitu pembicara, materi, suasana, dan sarana/prasarana. Adapun hasilnya sebagai berikut (Tabel 2):

Tabel 2. Nilai Kepuasan Pelaksanaan Pelatihan

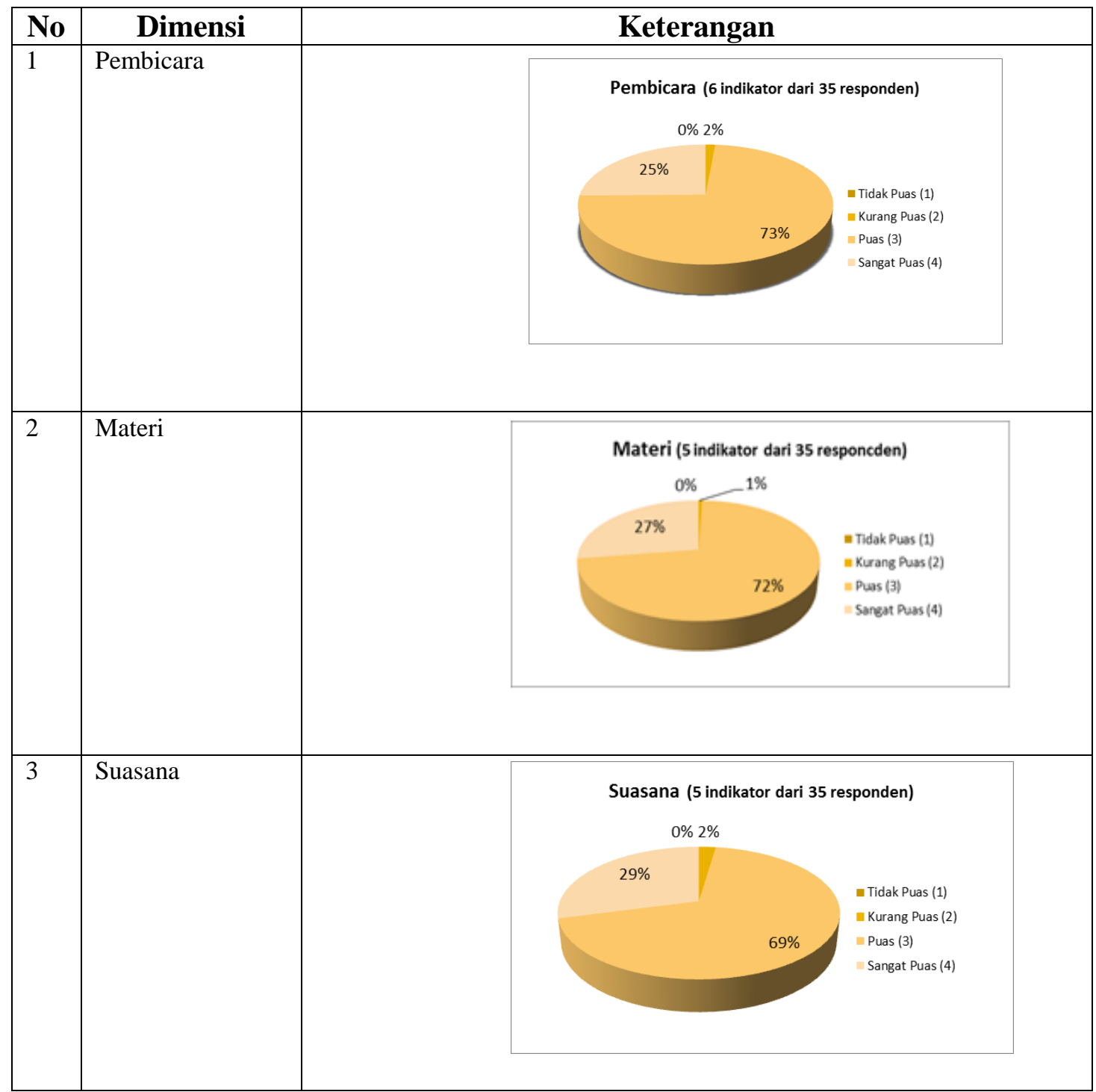




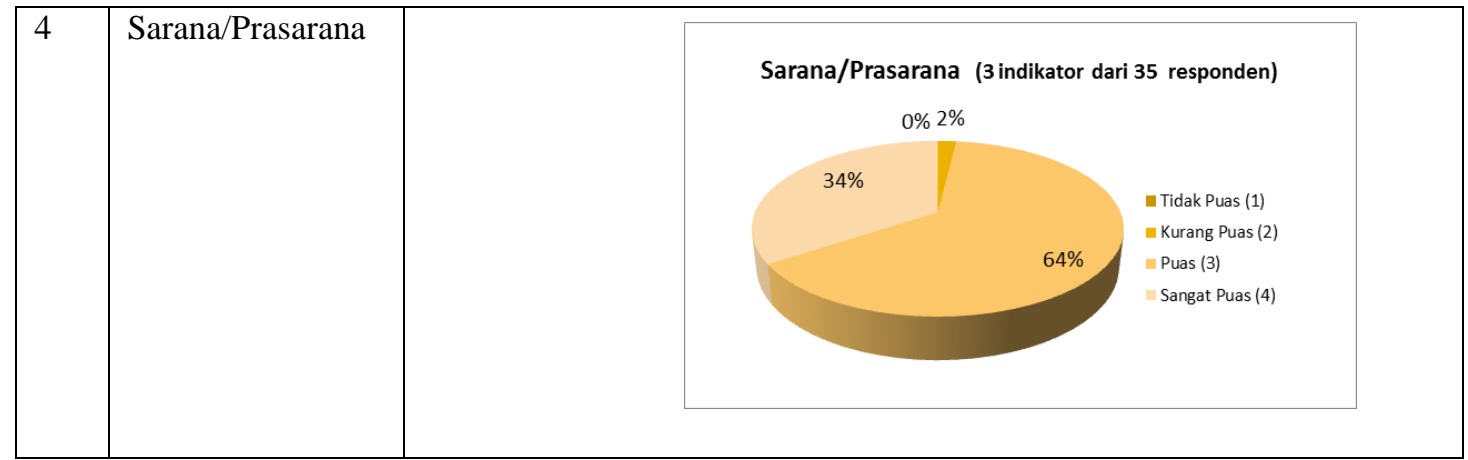

Pada Tabel 2 tampak, tingkat kepuasan Pembicara dari 35 peserta dengan 6 indikator pertanyaan sebanyak $73 \%$ peserta puas, $25 \%$ sangat puas, 2 $\%$ kurang puas. Hal ini menunjukkan bahwa peserta rata-rata puas dan antusias mengikuti kegiatan Pengabdian Kepada Masyarakat. Dari Materi Pelatihan sebanyak $72 \%$ peserta puas, 27 $\%$ sangat puas, $1 \%$ kurang puas. Hal ini menunjukkan bahwa peserta rata-rata puas dengan materi yang diberikan untuk peserta.

Suasana pelatihan sebanyak 69 $\%$ peserta puas, $29 \%$ sangat puas, $2 \%$

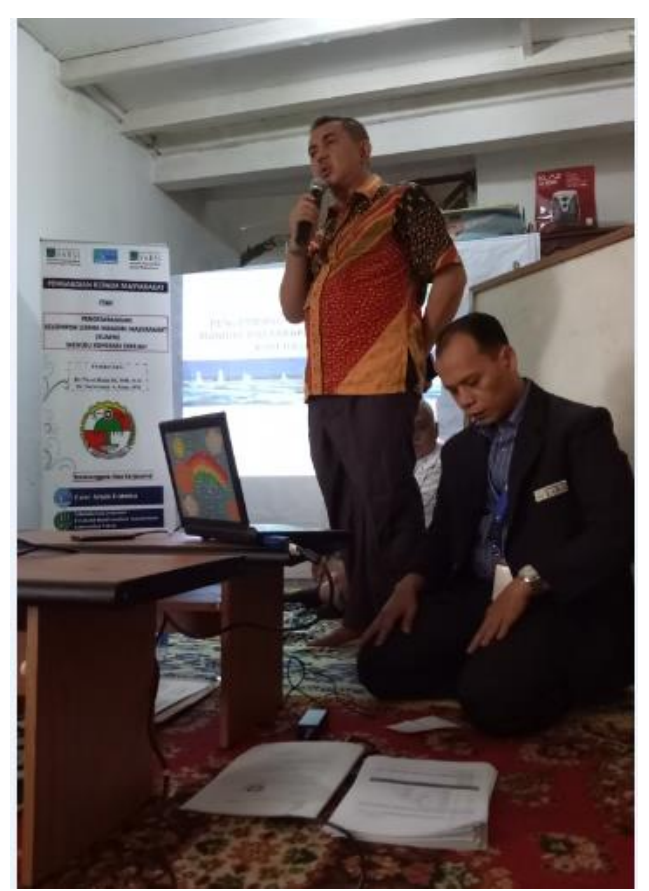

Gambar 3. Pembicara Pelatihan Koperasi Syariah

\section{Kemampuan Pre dan Post Test} Peserta

Pelaksanaan pengabdian kepada masyarakat memberikan sebanyak 6 (enam) butir pertanyaan terutama yang menyangkut pengetahuan tentang koperasi syariah. Adapun hasilnya sebagai berikut (Tabel 3): 
Volume 3 Nomor 2, April 2018

Tabel 3. Rata-rata jawaban pre test dan post test

\section{Descriptive Statistics}

\begin{tabular}{lr|r|r} 
& \multicolumn{1}{c}{ Mean } & Std. Deviation & \multicolumn{1}{c}{ N } \\
\hline Pretest & 2,71 & 1,292 & 34 \\
\hline Posttest & 4,24 &, 855 & 34 \\
\hline
\end{tabular}

Pada Tabel 3 tampak, dari 34 peserta (satu peserta bias) dengan 6 butir pertanyaan sebelum diberikan materi rata-rata jawaban yang benar sebanyak 2,71. Sedangkan setelah diberikan materi peserta jawaban yang benar naik rata-rata sebanyak 4,24 (post test). Ini menunjukan ada perhatian dan peningkatan pengetahuan peserta.

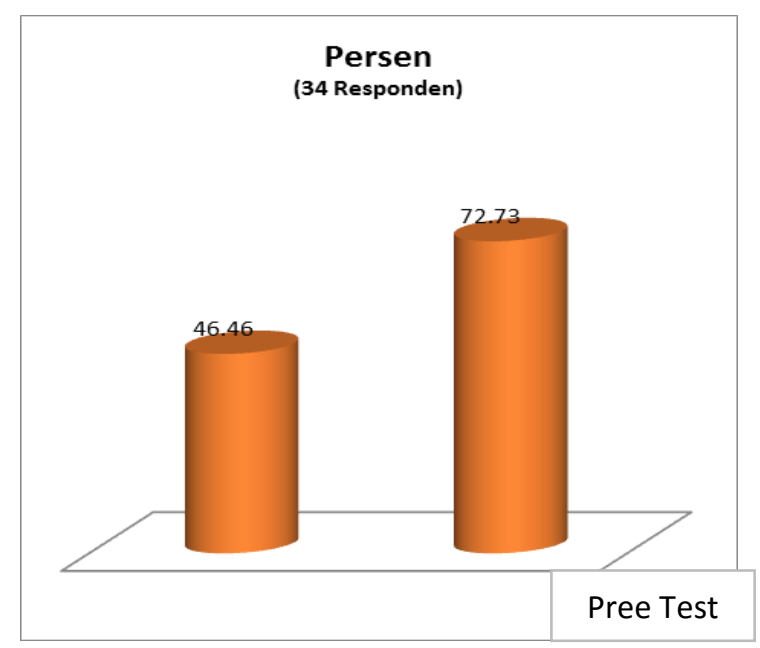

Gambar 4. Persentase Jawaban Peserta

Dari Gambar 4 butir pertanyaan sebelum diberikan materi rata-rata

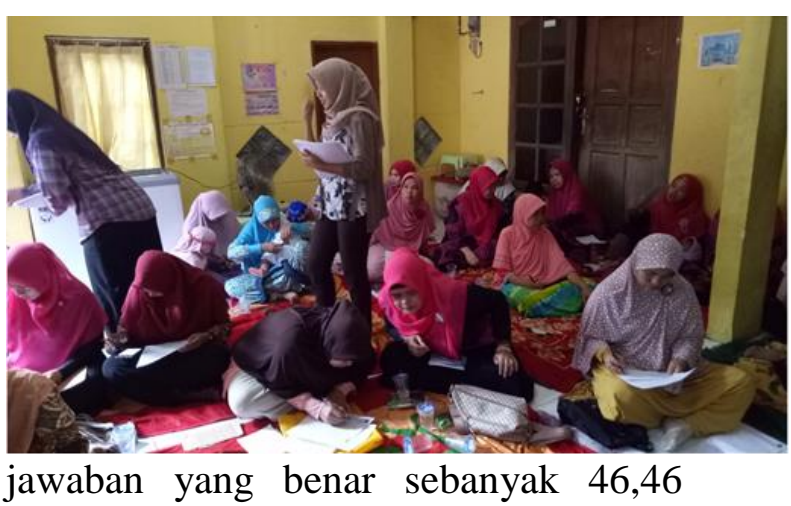

persen, sedangkan setelah diberikan materi peserta jawaban yang benar ratarata naik sebesar 72,73 persen (post test).

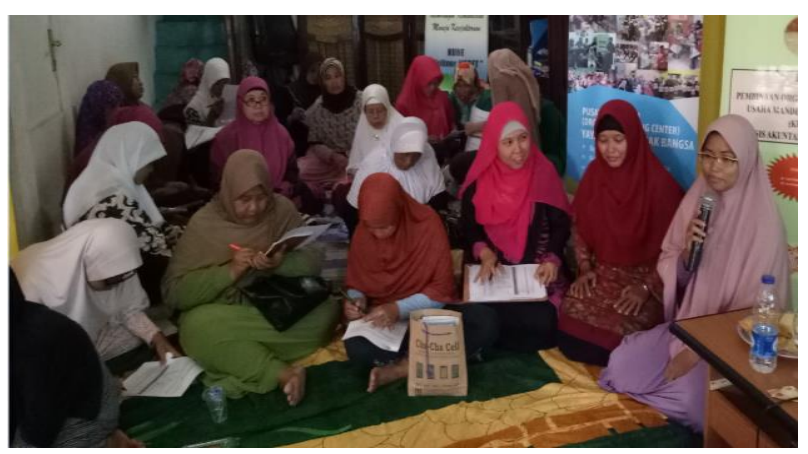

Gambar 5. Kegiatan pengisian Pre test dan Post Test

Maka terjadi kenaikan sebesar 26 persen, yaitu terutama pengetahuan Pos Test Koperasi Syariah. 
Tabel 4. Korelasi dan signifikansi

\begin{tabular}{|c|c|c|c|c|}
\hline \multicolumn{5}{|c|}{ Correlations } \\
\hline & & & Pretest & Posttest \\
\hline \multirow[t]{6}{*}{ Spearman's rho } & \multirow[t]{3}{*}{ Pretest } & Correlation Coefficient & 1,000 &, $359^{*}$ \\
\hline & & Sig. (2-tailed) & . & ,037 \\
\hline & & $\mathrm{N}$ & 34 & 34 \\
\hline & \multirow[t]{3}{*}{ Posttest } & Correlation Coefficient &, $359^{*}$ & 1,000 \\
\hline & & Sig. (2-tailed) & ,037 & \\
\hline & & $\mathrm{N}$ & 34 & 34 \\
\hline
\end{tabular}

*. Correlation is significant at the 0.05 level (2-tailed).

Dari Tabel 4 terlihat korelasi antara sebelum dan sesudah penyuluhan sebesar 0,359 atau 35,9 persen relatif korelasi rendah. Nnilai signifikansi (2tailed) $<0,05$, hal ini berarti pemberian pelatihan memberikan tambahan pengetahuan peserta.

\section{SIMPULAN}

Peserta kegiatan Pengabdian Kepada Masyarakat dihadiri seluruhnya berjenis kelamin perempuan, karena anggotanya merupakan ibu-ibu beberapa majelis taklim dan anggota KUMM. Usia perserta rata-rata berkisar antara $40 \mathrm{~s} / \mathrm{d} \quad 55$ tahun. Tingkat pendidikan rata-rata Sekolah Menengah.Rata-rata pekerjaan mereka adalah ibu rumah tangga dan wirausaha.

Dalam pelaksanaan kegiatan Pengabdian Kepada Masyarakat peserta menilai puas baik dari dimensi pembicara, materi pelatihan, suasana, dan sarana. Kamampuan pengetahuan pesertapun meningkat dari sebelum kegiatan dilaksanakan sampai acara selesai yang dibuktikan dengan pre test dan post test.

\section{DAFTAR PUSTAKA}

Aziz, Amin dan Rahmadi J.Hatta. 2006. Akuntansi BMT. Jakarta: Pinbuk Press

Huda, Nurul, Purnama Putra, Novarini, dan Yosi Mardoni. 2016. Baitul Mal Wa Tamwil sebuah Tinjauan Kritis. Jakarta: Penerbit Amzah

Irawan, R. 2013. Aspek Perpajakan Usaha Mikro, Kecil dan Menengah. The 6th NCFB and Doctoral Colloquium, Unika Widya Mandala Surabaya.

Laporan tahunan Kementerian Koperasi dan Usaha Kecil dan Usaha Menengah, http://www.depkop.go.id/beritainformasi/data-informasi/laporantahunan/

Murtiningtyas, T. 2013. Survei Pemahaman dan Kepatuhan Wajib Pajak (Studi pada UKM di 
Kelurahan Blimbing dan Lowokwaru Malang). The 6th $N C F B$ and Doctoral Colloquium Unika Widya Mandala Surabaya.

Mutiah, M, G.A. Harwida dan F.A. Kurniawan. 2011. Interpretasi Pajak dan Implikasinya Menurut Perspektif Wajib Pajak Usaha
Mikro, Kecil dan Menengah (Sebuah Studi Interpretif). Simposium Nasional Akuntansi (SNA)-XIV Aceh.

Zallum, Abdul Qadim. 1983. AlAmwal fi Daulah alKhilafah. Beirut: Darul 'Ilmi lil Malayin. 